\title{
News in Brief from Statistical Offices
}

\section{Croatia}

\section{Management Changes}

Mr. Ivan Rusan, M.A., the founder and director of the Croatian Information Documentation Referral Agency has been appointed the new Director-General of the Central Bureau of Statistics of the Republic of Croatia, starting in November 1995. Mr. Jakov Gelo, PhD., who was presiding this office during the last four years and who is one of the best known Croatian demographers, has taken a position as professor of the Faculty of Economics of the University of Zagreb.

\section{Statistical Legislation}

The transition period in the country has been very dynamic - the country has witnessed the passing of a few very important laws that will considerably influence statistics in the country. The laws referred to are the Law on National Statistics (1994), which has been brought up-to-date with international practice, the Law on National Classification of Economic Activities (1994), based upon the European classification of activities NACE - Rev. 1, and finally the Regulation on Classification of Business Entities according to the National Classification of Economic Activities - that have induced the updating of the Administra- tive Register of Enterprises, maintained by this office.

\section{Publications}

The Central Bureau of Statistics of the Republic of Croatia publishes regularly (since 1991) the Statistical Yearbook, bilingually in Croatian and English, to supply the widest possible audience with accurate and interesting information on Croatia. The Monthly Statistical Reports are also issued bilingually. From issue to issue the contents vary so that data are made available as soon as they are generated.

\section{Czech Republic}

\section{New Legislation}

On 15 June 1995, a new Law on State Statistical Service came into effect. The law is based on the same principles as similar laws in the EU countries.

\section{Publications}

The Czech Statistical Office continues to edit periodical publications according to the annual plan. A Statistical Yearbook and some other publications are in a Czech-English version. An EnglishFrench quarterly is also published. 
Meetings

A joint workshop with Eurostat on SNA for countries in transition took place from 16-20 October 1995.

Also a joint meeting with ILO on Statistical Treatment of Persons on Extended Types of Leave in the International Definitions of Employment and Unemployment took place in Prague from 15-17 November 1995.

\section{Denmark}

\section{Management Changes}

On 1 April 1995, Mr. Jan Plovsing, Director-General of the Danish National Institute of Social Research took over as Director-General of Statistics Denmark. He succeeds Mr. Hans Zeuthen who resigned earlier this year.

\section{Publications}

Amongst other publications, Statistics Denmark has published in 1995 Statistics on Persons in Denmark - A Register-based Statistical System. With financial support from Eurostat, this report was made available to international readers through an English translation as a Eurostat statistical document. The publication is a general account of the Danish system of register-based statistics with the main emphasis on socio-demographic statistics. The book discusses the development of the system and the thinking that lies behind its present structure. Register legislation, the dissemination of register statistics and documentation are considered and problems relating to data quality are discussed.

\section{Estonia}

New Tasks

Since July 1995, the Statistical Office of Estonia started a regular monthly survey of incomes and expenditures of Estonian households.

At the end of 1994, the Statistical Office of Estonia carried out a Living Conditions Survey with the help of the Norwegian Institute for Applied Social Science (FAFO). At the same time, similar surveys were made in Latvia, Lithuania and some cities in Russia (Moscow, St. Petersburg and Kaliningrad). Standard tabulations are being compiled. A special publication on these surveys will be published in five volumes in 1995 (three volumes have already been published). The next survey has been planned for 1998 .

Also in 1994, the Statistical Office of Estonia carried out the Estonian Family and Fertility Survey (inquiry of women). Standard tabulations are being compiled. A national report on the survey will be prepared in 1995-1996.

In 1996, a Health Survey will be carried out from January to March 1996 and from October to December 1996 an Estonian Family and Fertility survey will be prepared.

\section{Finland}

\section{Management Changes}

Mr. Timo Relander, General Director of Statistics Finland, returned to his post in May having been on leave for almost three years working at the Prime Minister's Office where he carried out the duties of the Head of Office. 


\section{Publications}

Statistics Finland has set up an international statistical news service known as the International Business Statistics. This service publishes a newsletter on economic statistics once a month, which covers the following areas: the European Union, the Baltic countries, Russia, Eastern Europe and the Pacific Region. The newsletter includes the main economic indicators in statistical format together with maps and economic news based on statistics.

\section{Greece}

\section{Meetings}

The National Statistical Service of Greece organized two international conferences, the Conference for the Establishment of the Association of Balkan Statisticians and the Conference on the Integrated Local Information Systems, which were held at Ancient Olympia in October 1995.

An international Work Session on Statistical Data Editing organized by the National Statistical Service of Greece jointly with the UN/ECE was held in Athens in November 1995.

New tasks

Two new surveys are to be conducted by the Population Directorate of the National Statistical Service of Greece in the near future. These are: the survey on emigration and immigration and the survey on the fecundity of the population.

A new survey on the local units of enterprises is to be conducted by the Census Directorate. This survey replaces the
Census of Establishments, which was conducted every five years and is no longer executed by the National Statistical Service of Greece.

The Primary Sector Directorate will conduct during 1996 an agricultural 'mini census' to:

- update identification of the Heads of agricultural livestock holdings;

- to identify new holdings;

- identify holdings that have closed;

- identify any changes that have occurred in the sizes of holdings (e.g., in the area, in number of animals, number of trees, etc.).

A revision and harmonization of the Consumer Price index is under way.

\section{Iceland}

\section{Meetings}

Statistics Iceland will be hosting the 5 th Independent IAOS Conference in Reykjavik, Iceland during 1 to 5 July 1996.

The programme will comprise seven sessions with contributed papers on the following subjects:

- Utilization of accounting and information system of firms for data collection (Ad Willeboordse, CBS Netherlands);

- Quality issues associated with the use of administrative records (Ib Thomsen, Statistics Norway);

- Combining data from surveys and administrative records (Tim Holt, CSO United Kingdom);

- GIS for urban and regional statistics (Asta Manninen, The City of Helsinki Information Centre, Finland);

- Creating user-oriented statistical 
agencies (Len Cook, Statistics New Zealand);

- New Methods for dissemination of official statistics: The Internet possibilities and problems for official statistics (John Cornish, Australian Bureau of Statistics);

- New Methods for dissemination of official statistics (Lars Thygesen, Statistics Denmark).

Simultaneous interpretation in English and French will be provided.

Contribution of papers related to any of the above topics is welcome. Should there be a number of them, the programme will include parallel sessions running alongside the already scheduled sessions. Those who are interested in participating or submitting papers should contact the organizers before 1 January 1996.

Any inquiries or notifications should be addressed to:

5 th Independent IAOS Conference KOM, Kynning Og Markaour hf.

c/o Guolaug B. Guojonsdottir

Austurstraeti 6, IS 101 Reykjavik, Iceland

Tel: (+354) 5622411

Fax: (+354) 5623411

E-mail: gbgkom@ismennt.is

\section{Romania}

\section{Statistical Legislation}

A strategy of developing the statistical system so as to achieve autonomous statistics at a scientific and high quality level has been established.

The official statistics organization is stipulated by the Governmental Ordinance No. 9/1992 approved by the Law
11/1994. The National Commission for Statistics (NCS) is authorized by the Government to establish, in accordance with the provisions of the Ordinance, the indicators system, nomenclatures, classifications, techniques of registering and processing, data publishing and dissemination, to ensure the full impartiality and reality of researches and statistical data.

\section{Meetings}

The NCS was host to the Regional Software Workshop, which took place from 28 November to 7 December 1995 in Bucharest on the project Computer Software and Support for Population Activities (POP-MAP). It was sponsored by the United Nations Population Fund.

\section{New Task}

The NCS is going to carry out a number of statistical regional projects using methodologies that will assure comparable data for all countries participating in the projects.

The NCS is taking part in carrying out some regional projects at European level, which came after signing the Common Cooperation Declaration among national statistical offices between several transition countries and Eurostat, as well as the Common Declaration of Statistical Cooperation between the NCS and Eurostat.

The NSC has signed a contract to carry out the PANEL survey on newly created enterprises. It is a regional project, financed and initiated by Eurostat, having as objective the supply of statistical data on the conditions for newly created economic agents, their evolution and characteristics of entrepreneurs who initiated them. 
Concerning the Households Labour Force Survey (AMIGO), the results for 1995 have already been included this year. A quarterly survey has also been designed and will be operative next year.

\section{Publications}

The NCS has a number of bilingual publications (Romanian-English) or translated publications into English that are regularly distributed, such as:

- The Statistical Yearbook of Romania (bilingual);

- Population and Housing Census of January 1992 - general results (English);

- Foreign Trade of Romania (19901994) (bilingual);

- Tourism in Romania (1993-1994) (bilingual);

- Household Labour Force Survey (English);

- Monthly Statistical Bulletin (English);

- Statistical Bulletin on Prices (monthly, bilingual);

- Statistical Bulletin on Foreign Trade (monthly, bilingual);

- Quarterly Statistical Bulletin (bilingual).

\section{Slovenia}

\section{Meetings}

In June 1995 Eurostat organized the Workshop on Migration Statistics jointly with the Statistical Office of the Republic of Slovenia. The participants were 46 delegates from statistical offices and from institutions that provided migration data for statistical purposes from 17 countries from the Central Eu- ropean Initiative and Eastern Europe and experts from Eurostat, chaired by Ms. Thana Chrissanthaki. It took place at Bled, a small tourist resort in the Slovenian Alps.

Several topics were presented; all were followed by fruitful discussions.

The situation in the Central and Eastern European countries concerning migration statistics was presented by $\mathrm{Mr}$. Michel Poulain. Mr. Harri Cruisen reviewed the use of migration statistics in the latest projects, discussed issues on output, analysis and projection modelling and gave some recommendations. His contribution to Slovenian national population projection was presented when Statistics Finland had just finished the respective project publicizing the results up to 2020.

The central topic was the draft proposal for the revision of the UN recommendations on international migration statistics. Mr. Curt Grundstrom presented the framework for the draft proposals and participants took the opportunity to contribute to the discussion before the meeting of the expert group for migration statistics, under the Statistical Commission of the UN, New York, July 1995. A final topic was the legislative background.

A visit to the central and local population registers was organized and explained.

Among the conclusions of the workshop were proposals of the following topics for the next meeting: bilateral exchange of data on international migration and their comparison, migration definitions versus census definitions and international versus internal migration definitions. 


\section{Turkey}

\section{Meetings}

Concerning the international meetings, two training courses for the statisticians of the Caucasian and Central Asian Republics will be conducted in November at the State Institute of Statistics (SIS). The first course, will be on Agricultural Censuses and Surveys and the subject of the second course is the Industrial Censuses and Establishment Surveys. These courses will be carried out in the framework of the technical assistance programme being implemented by the SIS Office for the Caucasian and Central Asian Countries. The countries of Bosnia and Herzegovina and the former Yugoslav Republic of Macedonia will be included in this programme in the near future.

In the context of the European Comparison Programme, a Workshop for the Caucasian and Central Asian Republics was held from 20-24 November 1995 at the SIS in collaboration with OECD.

The 51st Session of the International Statistical Institute (ISI) will be held in Istanbul from 18-27 August 1997 under the responsibility of SIS. The Session will, like the previous ones, aim to improve discipline of statistics, to encourage international cooperation and association between statisticians and the exchange of their professional knowledge and findings, and to promote the use of the most appropriate statistical methods in all countries. A large number of people including statisticians, scientists, academics and other interested persons are expected to participate in the 51st Session of the ISI in Istanbul.

\section{Publications}

The regular publications of the SIS are bilingual, i.e., Turkish and English, and can be used by an international audience. Some special issues published recently, for both national and international audiences, are: Ottoman Foreign Trade in the 19th Century, Historical Statistics Series, Volume I; The Population of Turkey, 1923-1994, Demographic Structure and Development with Projections to the Mid-21st Century; and Employment, Unemployment and Wages in Tur$k e y$ (ILO/SIS joint publication).

In the framework of the Black Sea Economic Cooperation, the publications entitled Social and Economic Indicators of the Black Sea Economic Cooperation Countries and Turkey's Foreign Trade with the Black Sea Economic Cooperation Countries have been prepared and distributed to the relevant organizations in the participating states.

\section{UNSD}

\section{Regional Work}

There has been considerable progress in regional work on ICP for reference year 1993 in the past months. The 1993 round was completed for the European Union and OECD member countries covered in the joint Eurostat-OECD programme. The results of Eastern European countries (15 countries), including former USSR republics, were finalized in September and the report of the European comparison will be prepared by the ECE before the end of 1995. In ESCAP, the comparison covering 17 countries was completed last fall. The African comparison, conducted by EuroCost with 22 countries participating, was fi- 
nalized after the results were discussed in a meeting in September 1995. Results of the eight Central Asian former USSR countries will become availabe next year.

Developments in the ECLAC and Caribbean regions, as well as details of the joint efforts of the World Bank, UNSD and the Regional Commissions to extend country coverage to further nations on all continents, will be covered in the next issue of this journal.

\section{SNA Newsletter}

SNA News and Notes, a biannual information service was launched by the Intersecretariat Working Group on National Accounts (ISWGNA) in February 1995. The newsletter is edited at UNSD, based on contributions received from ISWGNA members, constituted by five organizations, United Nations (Statistical Division and Regional Commissions), the European Union, OECD, World Bank and IMF. The second issue of the SNA newsletter has just been released. The newsletter is meant to be a forum of information and dialogue between experts working in various fields around the world, but all related to the implementation of the new (1993) SNA. Interested persons and organizations should contact UNSD to obtain free copies on a regular basis. Address: SNA News and Notes, UNSD, United Nations, Room DC2-1714, New York, NY 10017, USA Tel.: +1-212 963-4854, fax: (+1-212) 963-4116, Email: SNA@UN.ORG.

\section{Price Statistics Task Force Cancelled}

The Inter-Agency Task Force on Price Statistics, including the ICP was cancelled by the UN ACC Subcommittee on Statistical Activities at its last meeting held in June 1995. The report of the Subcommittee states that this Task Force has mainly concluded its initial task bearing in mind that there was no duplication revealed in the activity by international organizations in this field. Therefore, noting the lack of resources and interest in continuation of the work by some members, it was agreed that the Task Force would be terminated and the topic might be taken up by the Working Group on Critical Problems in Economic Statistics. 